Ada Wolarek (a.wolarek4@gmail.com)

Michalina Zyga (zyga.michalina@gmail.com)

Student, Wydział Architektury, Politechnika Krakowska im. Tadeusza Kościuszki

\title{
Miasto odporne a dostępność piesza. Analiza założeń planistycznych i ich realizacji w wybranym obszarze Nowej Huty
} Resilient city and walkability. Analysis of the plan and its implementation in a selected area of Nowa Huta

\section{Streszczenie}

Tematem artykułu jest problematyka pieszej dostępności w kontekście tworzenia miast odpornych. Na podstawie analizy oryginalnych planów Nowej Huty sprawdzono stopień, w jakim pierwotne założenia odnosiły się do tego problemu. Opracowana metoda badawcza pozwala określić skalę oddziaływania danych cech, ich realizację oraz stan obecny. Celem artykułu jest wskazanie obszarów potencjalnych działań na osiedlu Szkolnym, mogących wpłynąć na jakość dostępności pieszej i odporności całej jednostki.

Słowa kluczowe: miasto odporne, dostępność piesza, Nowa Huta

Abstract

The topic of the article is a walkability in the context of resilient cities. The analysis of Nowa Huta original plans allows to define how the concept was realized in the past and what is the current state of it. The article points out problems and potential actions that may improve the quality of life and walkability in Szkolne Estate.

Keywords: resilient city, walkability, Nowa Huta 


\section{WSTĘP}

Miasto od wieków odzwierciedla aktualne osiągnięcia ludzkości. Jego obraz zmienia się wraz z postępem, metamorfozą stylu życia mieszkańców czy rozwojem techniki (Czornik, 2013). Obecnie w wielu strukturach miejskich podejmowane są próby odchodzenia od rozwiązań komunikacyjnych zdominowanych przez ruch samochodowy na rzecz jednostek odpornych, uwzględniających filozofię „krótkich odległości” (Skrzypek, 2016). Dostępność piesza zdaje się stanowić podstawę dobrze zaprojektowanego miasta. Od poziomu jej realizacji w poszczególnych obszarach zależy odporność organizmu miejskiego. Ponadto niewątpliwie jej koncepcja wpisuje się w jedną z podstawowych cech odporności, jaką jest modułowość, a więc podział miasta na autonomiczne jednostki (Kete, 2015; Czachor, 2019; Mehmood, 2016; Mendizabal et al., 2018; Sharifi, Yamagata, 2014). Badania pokazują, jak ważna jest aktywizacja pieszych, stworzenie im odpowiednich przestrzeni, oraz jak zmienia się percepcja miasta w zależności od sposobu poruszania (Gehl, 2014; Skrzypek, 2016). Trudnością, przed jaką stają urbaniści i architekci, jest zachęcenie mieszkańców do poruszania się pieszo i korzystania z potencjału dzielnicy. Innymi słowy wyzwaniem staje się budowa odporności miasta poprzez rozwój wspomnianej koncepcji.

Pojęcie pieszej dostępności dotyczy głównie problematyki dostosowania przestrzeni do ruchu pieszego. Zazwyczaj w polskojęzycznych opracowaniach naukowych termin ten odpowiada anglojęzycznemu zwrotowi walkability, który nie posiada jednoznacznej definicji. Na podstawie studiów wielu badaczy można jednak stwierdzić, że jest to zbiór parametrów charakteryzujących dany obszar pod względem gęstości struktury zabudowy, stopnia przemieszania funkcji i bogactwa infrastruktury pieszej, które czynią go przyjaznym dla pieszych (Dovey, Pafka, 2019; Forsyth, 2015). Przeprowadzone badanie jest więc analizą stopnia dostępności pieszej, będącej jednym z „przymiotów środowiska zurbanizowanego” (Kenworthy, Newman, 2006; Poklewski-Koziełt, 2019).

Dostępność piesza zawsze stanowiła ważny element struktury miejskiej. Obecnie wiele projektów traktuje ją jako jedną z podstawowych wytycznych. W przeszłości również część założeń urbanistycznych była tworzona na podstawie idei miasta dostępnego pieszo. Za przykład może posłużyć projekt Nowej Huty z 1949 roku (Luchter, 2011; Paduchowski, 2012; Ptaszycki, 1953; Sumorok, 2015; Walczak, 2018). Interesującą kwestią jest stopień uwzględnienia dostępności pieszej w planach, początkowa realizacja oraz jej aktualny stan.

\section{METODA BADAWCZA}

Osiedla nowohuckie zaprojektowano zgodnie z ideą jednostki sąsiedzkiej C.A. Perry'ego. Jest to teoria „polegająca na tworzeniu osiedli przyjaznych obywatelom” (Smaga, 2012, za: Walczak, 2018; Marcinek, Myczkowski 2017; Sumorok, 2015; Mądrala, Piła, 2019; Klaś, 
2016). Budowa Nowej Huty rozpoczęła się przed ukończeniem ogólnego planu (Walczak, 2018; Klaś, 2016; Sumorok, 2015). Do celów badawczych wybrano osiedle Szkolne powstałe w roku 1956 (Walczak, 2018), w okresie po opracowaniu projektu Nowej Huty. Z tego powodu jest to zespół reprezentatywny dla badanego obszaru (il. 1, 2). Przedmiotem badań jest analiza pierwotnych rozwiązań planistycznych, zmian, jakie zaszły na osiedlu Szkolnym w Nowej Hucie względem oryginalnego projektu dzielnicy autorstwa S. Juchnowicza (Klaś, 2018), oraz ich powiązanie z kwestią pieszej dostępności. Ocena jej stopnia może być dokonana na podstawie wielu różnorodnych kryteriów w tym poprzez subiektywną ocenę dostępności przestrzeni widzianej oczami użytkownika.

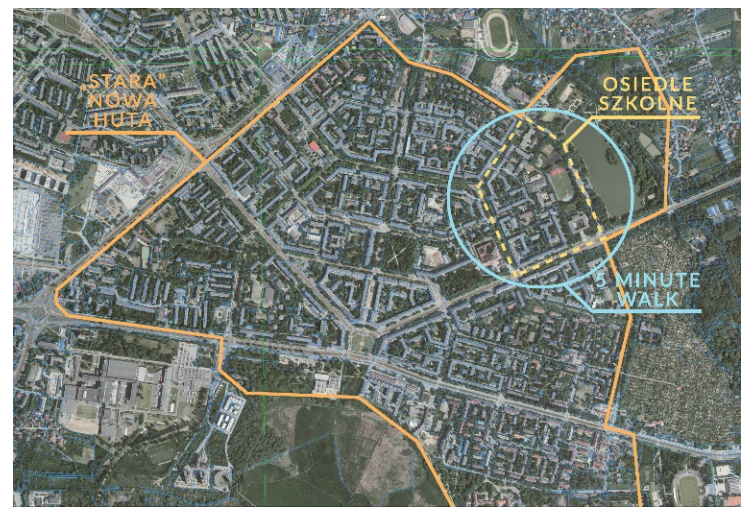

II. 1. Obszar najstarszej części miasta. Oprac. własne

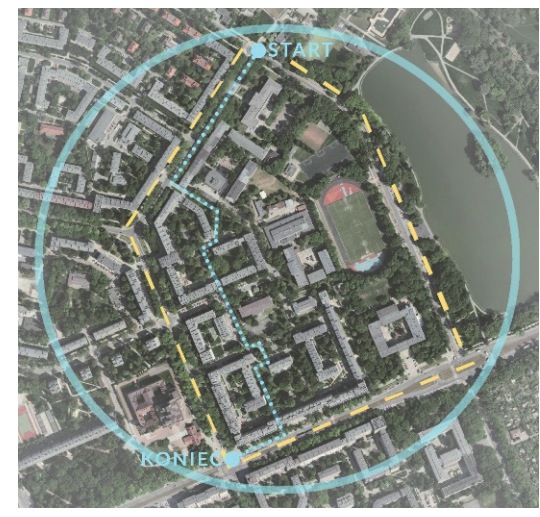

II. 2. Obszar osiedla Szkolnego, trasa badawcza. Oprac. własne

Ocena ta jest nierozerwalnie związana z fizyczną percepcją otoczenia, z warunkami środowiskowymi i architektonicznymi. Dlatego też pracę badawczą oparto na dwóch rodzajach analiz: analizie oryginalnych teoretycznych założeń planu oraz terenowej. W pierwszym etapie dokonano syntezy cech pierwotnego planu Nowej Huty i wyodrębnienia elementów

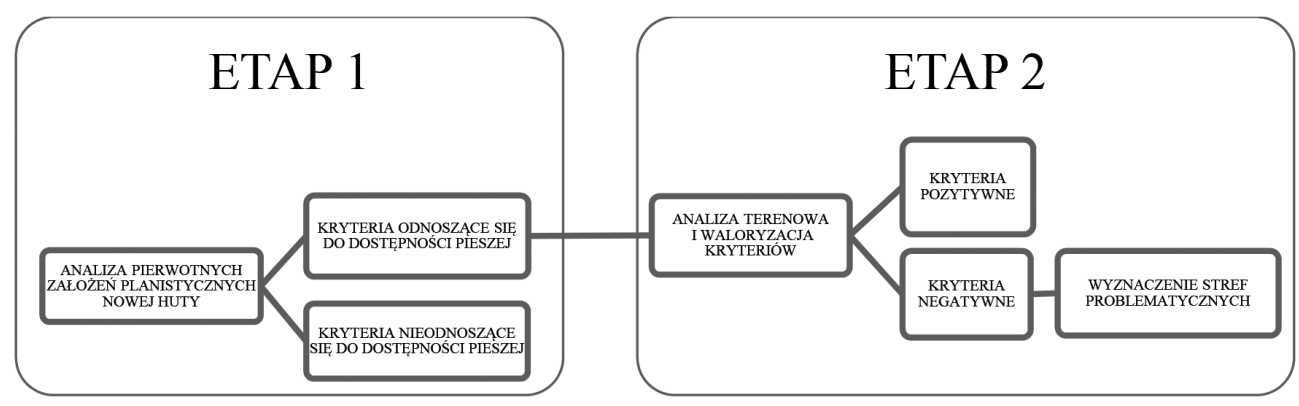

II. 3. Schemat prezentujący proces pracy badawczej. Oprac. własne 
mających wpływ na dostępność pieszą założenia. Następnie, zgodnie z przyjętymi kryteriami, stan aktualny rozwiązań przestrzennych został poddany waloryzacji jakościowej podczas analizy terenowej w dniu 21 marca 2021 roku. Ocenę sformułowano poprzez określenie „+", kiedy analizowane kryterium miało wpływ pozytywny, oraz „,-, kiedy miało wpływ negatywny. Celem obserwacji było zwrócenie uwagi na to, czy pierwotne założenia projektu z upływem czasu uległy rozmyciu, czy pozostały aktualne, w konsekwencji - czy dostępność piesza osiedla uległa pogorszeniu czy też poprawie.

\subsection{ORYGINALNY PLAN NOWEJ HUTY}

Pierwotny projekt Nowej Huty zakładał stworzenie miasta przyjaznego dla swoich mieszkańców na podstawie idei miasta idealnego i miasta-ogrodu (Obrał, 2013; Sumorok, 2015). Autorzy chcieli, żeby pracownicy mieli możliwość, po wypełnieniu codziennych obowiązków, korzystania z różnorodnych form wypoczynku oraz rozwijania się zarówno fizycznie, jak i umysłowo (Radłowska, 2008; Konarski, 2019; Szczypiór, 2020). To wszystko miało odbywać się wśród nowo projektowanych zespołów mieszkaniowych z pełną infrastrukturą handlowo-usługową, wszechogarniającą zielenią oraz rozbudowanym systemem ciągów komunikacyjnych (Sumorok, 2015). Założeniem była budowa Nowej Huty jako niezależnego miasta, jednak już w 1951 roku podjęto decyzję o przyłączeniu jej do Krakowa (Walczak, 2018). W konsekwencji obszar ten można postrzegać jako autonomiczny względem całego miasta.

\section{Etap 1. Analiza pierwotnych rozwiązań planistycznych Nowej Huty - wybór kryteriów}

W przeprowadzonym badaniu pierwotne założenia planu (Ptaszycki, 1953, Juchnowicz, 2008) postanowiono odnieść do problematyki dostępności pieszej, sprawdzić, czy i w jaki sposób zostały zrealizowane, oraz zweryfikować ich aktualny stan. Przyjęte przez twórców planu rozwiązania podzielono w tym celu na 5 kategorii pod względem: uwarunkowań lokalizacyjnych, funkcji, struktury urbanistycznej, zieleni oraz komunikacji (tab. 1).

Tabela 1. Pierwotne rozwiązania planistyczne Nowej Huty - wybór kryteriów do dalszej analizy

\begin{tabular}{|c|l|c|}
\hline \multirow{2}{*}{ Kategoria } & \multicolumn{1}{|c|}{ Kryteria szczegółowe } & $\begin{array}{c}\text { Znaczenie badanego } \\
\text { kryterium dla } \\
\text { dostępności pieszej }\end{array}$ \\
\hline \multirow{4}{*}{$\begin{array}{l}\text { Uwarunkowania } \\
\text { lokalizacyjne }\end{array}$} & Podział na autonomiczne jednostki sąsiedzkie & TAK \\
\cline { 2 - 3 } & Gęstość zaludnienia: 270-500 os./ha & TAK \\
\cline { 2 - 3 } & $\begin{array}{l}\text { Podział kwartału: zabudowa mieszkalna 67\%, } \\
\text { zabudowa usługowa 33\% }\end{array}$ & TAK \\
\hline
\end{tabular}




\begin{tabular}{|c|c|c|}
\hline \multirow{3}{*}{ Funkcje } & Bogate zaplecze handlowo-usługowe & TAK \\
\hline & $\begin{array}{l}\text { Partery przy głównych traktach przeznaczone na } \\
\text { lokale usługowe }\end{array}$ & TAK \\
\hline & $\begin{array}{l}\text { Osiedlowe obiekty gastronomiczne, kulturalne } \\
\text { i społeczne }\end{array}$ & TAK \\
\hline \multirow{8}{*}{$\begin{array}{l}\text { Struktura } \\
\text { urbanistyczna }\end{array}$} & Tworzenie przestrzeni wspólnych & TAK \\
\hline & Szerokie i jasne wnętrza urbanistyczne & TAK \\
\hline & Forma silna wprowadzająca poczucie bezpieczeństwa & NIE \\
\hline & $\begin{array}{l}\text { Zachowana różnorodność zabudowy mimo } \\
\text { stylistycznej uniformizacji }\end{array}$ & NIE \\
\hline & $\begin{array}{l}\text { Forma osiedla podporządkowana jego głównej } \\
\text { funkcji }\end{array}$ & NIE \\
\hline & $\begin{array}{l}\text { Hierarchizacja struktury zabudowy, czytelność granic } \\
\text { jednostki, luźna zabudowa wewnątrz kwartałów }\end{array}$ & TAK \\
\hline & Wnętrza urbanistyczne o zróżnicowanej skali & TAK \\
\hline & Stopniowanie poziomu prywatności wnętrz & TAK \\
\hline \multirow{2}{*}{ Zieleń } & Zieleń - aspekt estetyczny & TAK \\
\hline & Zieleń - aspekt funkcjonalny (strefa buforowa) & NIE \\
\hline \multirow{7}{*}{ Komunikacja } & Główny środek transportu - komunikacja publiczna & NIE \\
\hline & Brak przewidzianych parkingów & TAK \\
\hline & Rozwinięty system ścieżek rowerowych & NIE \\
\hline & Separacja ruchu pieszego i kołowego & TAK \\
\hline & Przejścia bramne w budynkach & TAK \\
\hline & Minimalizacja ruchu kołowego wewnątrz osiedla & TAK \\
\hline & $\begin{array}{l}\text { Brak konieczności przekraczania dróg tranzytowych } \\
\text { w obrębie osiedla }\end{array}$ & TAK \\
\hline
\end{tabular}

Źródło: opracowanie własne

Na podstawie analizy źródeł teoretycznych (Ptaszycki, 1953, Juchnowicz, 2008) można sformułować następujący wniosek: większość przyjętych rozwiązań pierwotnego planu miasta miała znaczenie dla dostępności pieszej.

\section{Etap 2. Analiza terenowa i waloryzacja cech}

Opracowaną metodę zastosowano do oceny każdego z wybranych rozwiązań pierwotnego planu. Dostępność pieszą w Nowej Hucie miał umożliwić przede wszystkim podział przestrzenny miasta na autonomiczne jednostki sąsiedzkie (Paduchowski, 2012; Sumorok, 2015) (il. 4). Zauważalna w układzie urbanistycznym jest czytelność granic zabudowy, zarówno 
między poszczególnymi jednostkami, jak i między wnętrzem a zewnętrzem pojedynczej struktury. Co ważne, zachowana została, zgodnie z pierwotnym planem, hierarchizacja struktury zabudowy (Sumorok, 2015). Zwarte ciągi budynków wyznaczają granice kwartału z zewnątrz jednostki oraz skrywają swobodniejszą zabudowę wewnątrz.

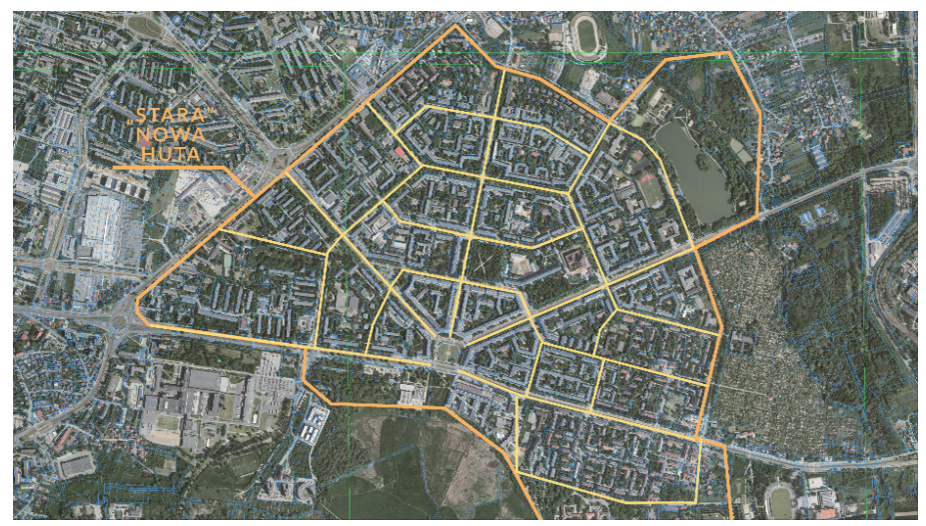

II. 4. Podział układu na autonomiczne jednostki. Oprac. własne

Kluczową kwestią w odniesieniu do problematyki dostępności pieszej jest możliwość realizacji potrzeb mieszkańców. Jednym z głównych założeń było stworzenie bogatego zaplecza handlowo-usługowego. Podczas badań terenowych odnotowano dużą liczbę lokali, jednak głównie na granicach jednostki. Wzdłuż istotnych ciągów komunikacyjnych usługi zlokalizowane zostały w parterach (il. 5). We wnętrzu osiedla funkcjonuje również kilka z nich, choć część lokali została opuszczona i obecnie nie jest w żaden sposób zagospodarowana. Schemat opracowany na podstawie analizy terenowej ukazuje lokalizację usług istniejących, nowych oraz nieistniejących (il. 6). Należy również zwrócić uwagę na wolnostojące budynki edukacyjne czy kulturowe, których na terenie osiedla Szkolnego nie brakuje. Zgodnie z pierwotnymi założeniami przedszkola i szkoły lokalizowano we wnętrzu jednostek (Klaś, 2018; 2016). Stanowią one dobre uzupełnienie powstałej infrastruktury społecznej.

Pod względem różnorodności oferowanych usług obszar można ocenić pozytywnie. Aspektem oddziałującym negatywnie jest brak lokali usługowych w strefie parteru wzdłuż niektórych ciągów komunikacyjnych. W danym przypadku północna granica jest jedynie korytarzem służącym komunikacji (il. 7). Brak „życia” wzdłuż chodników sprawia, że ulica jest bez wyrazu i nie zachęca pieszego do kontynuacji spaceru w tym kierunku.

Dostępność nierozerwalnie związana jest z problematyką komunikacji pieszej i kołowej. Twórcy pierwotnego planu zakładali, że mieszkańcy będą przede wszystkim poruszać się na piechotę. W tym celu zadbano o gęstą sieć ciągów pieszych oraz płynne połączenie wnętrza z zewnętrzem jednostki. Znakiem tego założenia są istniejące i funkcjonujące do dziś przejścia 


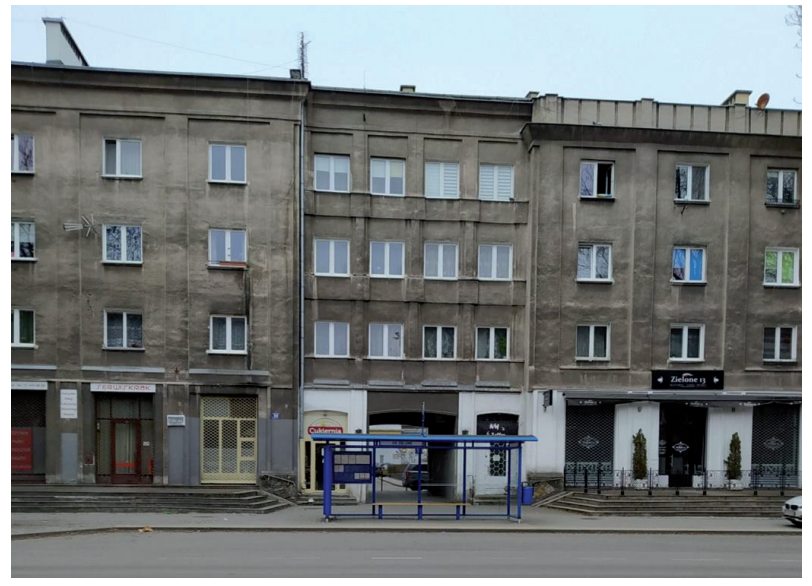

II. 5. Lokale usługowe w parterach na granicy jednostki. Fot. autor

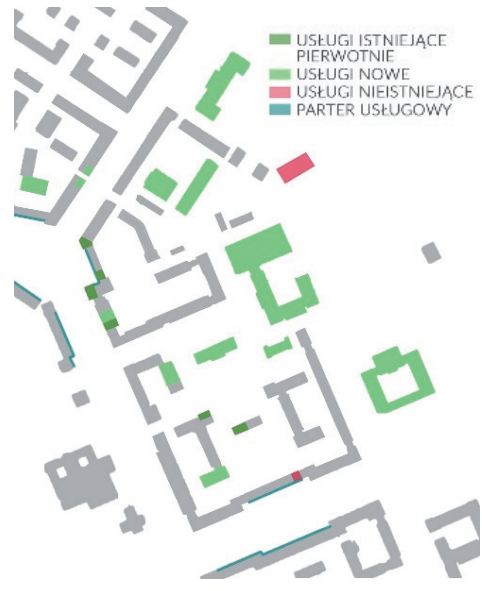

Il. 6. Schemat lokalizacji usług istniejących, nowych i nieistniejących. Oprac. własne

bramne w budynkach, które znacznie skracają drogę między poszczególnymi punktami. Stanowią jedną z najbardziej charakterystycznych cech osiedla, znacząco usprawniając komunikację pieszą oraz wzbogacając wizualnie zabudowę (il. 8). Co ważne, w obrębie osiedla nie ma konieczności przekraczania dróg tranzytowych (Walczak, 2018). Ponadto na zewnątrz jednostki większość ulic jest umiarkowanie ruchliwa, nie stwarza przeszkód dla pieszych. Mimo że pierwotnie nie przewidziano ruchu samochodów wewnątrz osiedla, powstałe wówczas wąskie i kręte uliczki obecnie skutecznie hamują rozwijanie większych prędkości (il. 9). Ponadto na obszarze całego zespołu obowiązuje ograniczenie prędkości pojazdów do $30 \mathrm{~km} / \mathrm{h}$, co w dużej mierze zwiększa bezpieczeństwo pieszych.

Mimo wielu pozytywnych przykładów, będących konsekwencją postawienia roli pieszego ponad samochodem, dostrzegalne są także negatywne skutki przyjętego rozwiązania. Należy zwrócić uwagę na przyczynę jego wyboru. Założenie, że mieszkańcy osiedla będą przemieszczać się przede wszystkim pieszo, nie było ideą motywowaną ekologicznymi i społecznymi względami towarzyszącymi nam dzisiaj, było to rozwiązanie przede wszystkim praktyczne, biorące pod

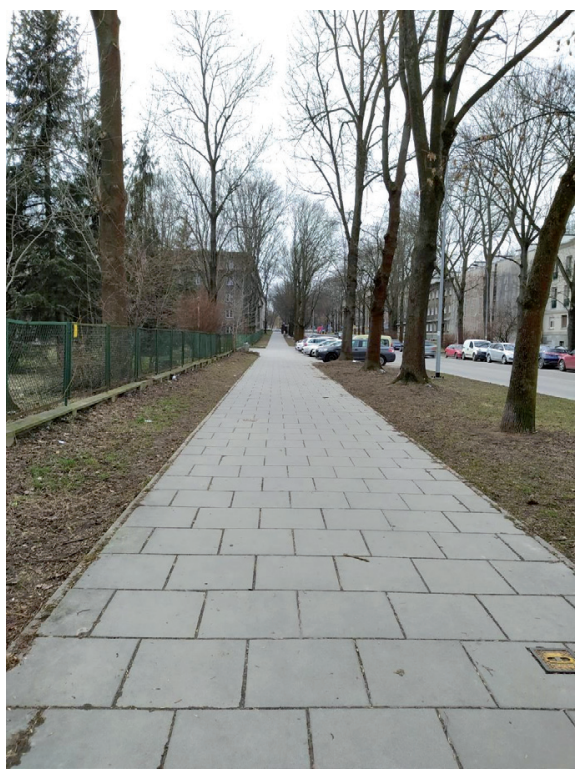

II. 7. Północna granica jednostki. Fot. autor 


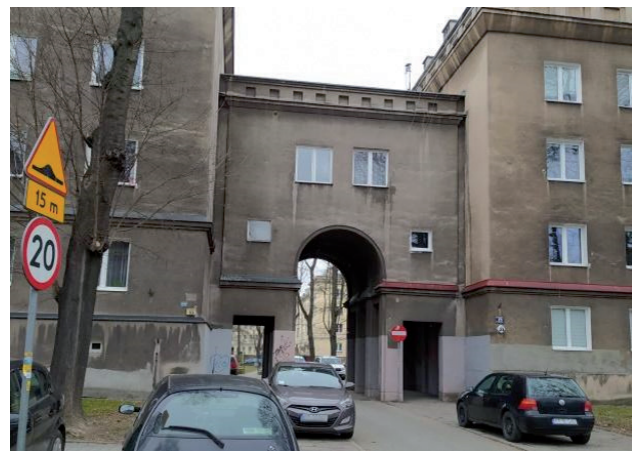

II. 8. Przejścia między budynkami w postaci bram. Fot. autor

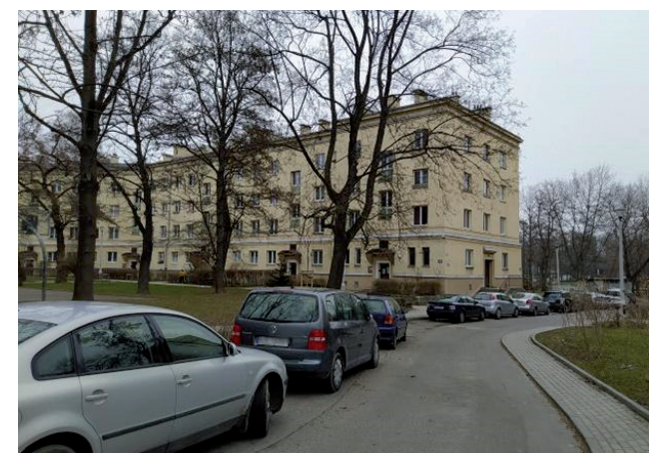

II. 9. Wąskie uliczki wewnątrz kwartału. Fot. autor

uwagę okoliczności i warunki odpowiednie dla tamtego okresu. Mieszkańcy osiedla mieli korzystać ze specjalnie utworzonej linii tramwajowej, nie z samochodów. Atrakcyjność przestrzeni pieszej zaczęła więc spadać wraz ze wzrostem liczby posiadanych przez lokatorów aut. Miejsca wcześniej zaplanowane jako szerokie wnętrza, przeobraziły się w parkingi, o których twórcy planu Nowej Huty nie myśleli w latach 50. XX wieku (Obrał, 2013).

Podczas obserwacji terenowej kwestia braku przewidzianych miejsc parkingowych była problemem najbardziej zauważalnym i najmocniej wpływającym na odbiór przestrzeni przez pieszego. Na wyznaczonej trasie napotkano tylko jedną strefę, w której wygospodarowano wolną przestrzeń na parking, znajdującą się przy wjeździe do wnętrza jednostki. W pozostałej części obszaru samochody często stały na chodnikach i trawnikach, zmuszając pieszych do zejścia na jezdnię lub kluczenia między pojazdami (il. 10). Pomijając oczywisty aspekt fizycznej, bezpośredniej przeszkody, jaką stanowi samochód zaparkowany na chodniku, subiektywnym odczuciem towarzyszącym spacerowi przez osiedle było wrażenie, że przechodzimy przez niekończący się parking. Pozytywne odczucia wywoływane atrakcyjnością zielonych wnętrz osiedla Szkolnego, uległy rozmyciu poprzez utratę pierwotnego podziału na ciągi piesze i kołowe.

W pierwotnym projekcie dużą uwagę przywiązywano do wnętrz urbanistycznych, w których mieli spędzać czas mieszkańcy osiedla. Z tego powodu zachowano dobre proporcje między zabudową a przestrzenią pomiędzy budynkami. Ponadto niezależnie od funkcji obiektu każdy został utrzymany w podobnej skali, dostosowanej do człowieka. Podczas badań terenowych odnotowano różny poziom otwartości wnętrz. Pomiędzy jednostkami są to głównie wnętrza ulic, otoczone szczelnie zabudową z dwóch stron, również wewnątrz zespołu większość jest zamknięta, ale szeroka i nieprzytłaczająca. Pierwotny plan traktował pieszego jako „wędrowcę” pomiędzy budynkami. Projektantom zależało na tym, żeby jego droga nie była zbyt monotonna (Sumorok, 2015; Mądrala, Piła, 2019). W tym celu chciano stworzyć wnętrza o zróżnicowanej skali. Miało to urozmaicić spacer i zachęcić do przejścia przez 
osiedle. Cechą wspólną każdego z wnętrz jest zieleń, która spaja układ w całość. W obrębie jednostki zaplanowano dużą ilość zieleni, która pełni w niej głównie funkcję estetyczną. Chodniki prowadzone wśród trawników obsadzone są częściowo krzewami, a cień zapewniają liczne drzewa. Obecnie na osiedlu znaleźć można także nowe nasadzenia, które mają dogęścić zieloną strukturę jednostki.

W przypadku przestrzeni wspólnych na terenie osiedla Szkolnego wszystkie pierwotne rozwiązania miały bardzo dobry wpływ na

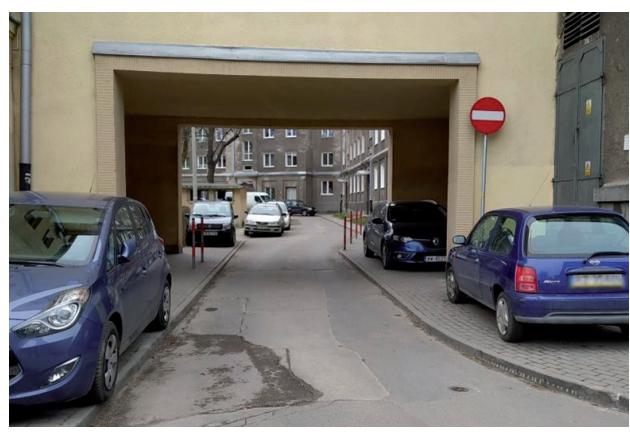

II. 10. Samochody zaparkowane na chodnikach. Fot. autor jakość życia mieszkańców. Jednakże aspektu tego nie można ocenić w zupełności pozytywnie ze względu na aktualny stan analizowanych skwerów i dziedzińców. Paradoksalnie to właśnie obecność wydzielonej przestrzeń wspólnej - placu zabaw - staje się elementem, który jednocześnie poprawia i pogarsza jakość przestrzeni pieszej. Mimo ożywienia i ruchu, jakie wprowadza do wnętrza, jest też bezpośrednią barierą ze względu na okalające go ogrodzenie (il. 11). Inną kwestią jest zaniedbanie i stopniowe niszczenie infrastruktury niewielkich placów, które pierwotnie stanowiły atrakcyjne punkty we wnętrzu osiedla. Nieaktywna fontanna, nieliczne ławki, brak różnorodności dostępnych aktywności w przestrzeni publicznej, tworzenie stref skierowanych do jednej grupy użytkowników (place zabaw) - zaobserwowana sytuacja obecnie nie wpływa dobrze na atrakcyjność osiedla (il. 12). Dzisiaj, miejsca te wymagają remontu i rewitalizacji, by ponownie przyciągać do siebie mieszkańców, zachęcać do spotkań i korzystania ze wspólnej przestrzeni sąsiedzkiej.

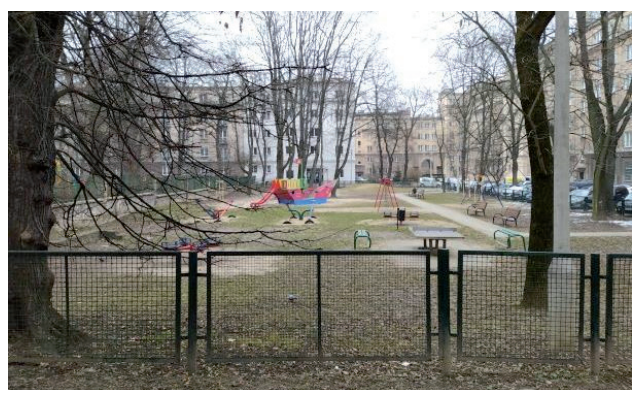

II. 11. Ogrodzenia przestrzeni wspólnych. Fot. autor

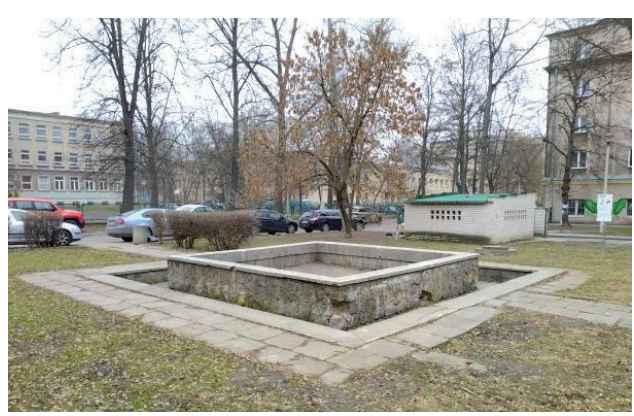

II. 12. Przestrzenie wymagające rewitalizacji.

Fot. autor

Analizując strukturę urbanistyczną zespołu, nie sposób pominąć aspektu prywatności wnętrz. W momencie przekraczania czytelnej granicy między zewnętrzną przestrzenią, pełną ruchu i miejskiego zgiełku, a cichym i spokojnym wnętrzem wyczuwalna jest 
hierarchizacja poszczególnych przestrzeni. Mieszkańcy, znając strukturę swojego osiedla, łatwo odnajdują się w jego wnętrzu, jednak z perspektywy osób „z zewnątrz” można odczuć pewnego rodzaju dyskomfort. Zdecydowanie lepiej odebrano podczas badań przestrzenie na zewnątrz jednostki, które nie mają tak ściśle określonego adresata.

Tabela 2. Waloryzacja kryteriów poddanych analizie odnoszących się do dostępności pieszej

\begin{tabular}{|c|c|c|c|c|}
\hline Kategoria & Pierwotne założenia & $\begin{array}{c}\text { Wnioski z analizy terenowej } \\
\text { wg kryteriów szczegółowych } \\
\text { zawartych w tab. } 1\end{array}$ & Waloryzacja & $\begin{array}{l}\text { Aktualny } \\
\text { stan }\end{array}$ \\
\hline \multirow{2}{*}{ 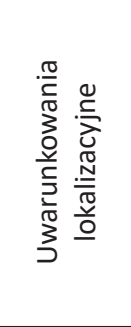 } & $\begin{array}{l}\text { Podział na } \\
\text { autonomiczne } \\
\text { jednostki sąsiedzkie }\end{array}$ & $\begin{array}{l}\text { Czytelny układ urbanistyczny } \\
\text { jednostek }\end{array}$ & 3 & + \\
\hline & $\begin{array}{l}\text { Gęstość zaludnienia: } \\
270-500 \text { os./ha }\end{array}$ & $\begin{array}{l}\text { Obecna gęstość zaludnienia } \\
\text { (Państwowa Komisja Wyborcza, } \\
\text { 2018) spełniająca standardy miast } \\
\text { dostępnych pieszo (Public Square. } \\
\text { A CNU Journal, 2021) - ok. } 50 \text { os./ha }\end{array}$ & 2 & $+/-$ \\
\hline \multirow{3}{*}{ 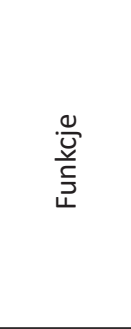 } & $\begin{array}{l}\text { Bogate zaplecze } \\
\text { handlowo-usługowe }\end{array}$ & $\begin{array}{l}\text { Lokalizacja usług głównie na } \\
\text { granicach jednostki }\end{array}$ & 3 & + \\
\hline & $\begin{array}{l}\text { Partery przy głównych } \\
\text { traktach przeznaczone } \\
\text { na lokale usługowe } \\
\end{array}$ & $\begin{array}{l}\text { Lokalizacja usług w parterach przede } \\
\text { wszystkim przy głównych osiach } \\
\text { komunikacyjnych }\end{array}$ & 3 & $+/-$ \\
\hline & $\begin{array}{l}\text { Osiedlowe obiekty } \\
\text { gastronomiczne, } \\
\text { kulturalne i społeczne }\end{array}$ & Funkcjonujące usługi na osiedlu & 2 & + \\
\hline \multirow{5}{*}{ 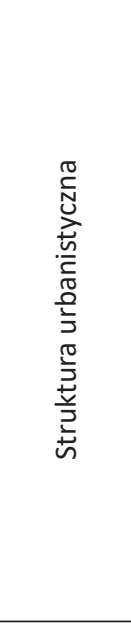 } & $\begin{array}{l}\text { Tworzenie przestrzeni } \\
\text { wspólnych }\end{array}$ & $\begin{array}{l}\text { Jednostka mieszkalna projektowana } \\
\text { z przestrzeniami wspólnymi, obecnie } \\
\text { konieczna rewitalizacja }\end{array}$ & 3 & - \\
\hline & $\begin{array}{l}\text { Szerokie i jasne } \\
\text { wnętrza urbanistyczne }\end{array}$ & $\begin{array}{l}\text { Wnętrza urbanistyczne o dobrych } \\
\text { proporcjach }\end{array}$ & 1 & + \\
\hline & $\begin{array}{l}\text { Hierarchizacja } \\
\text { struktury zabudowy, } \\
\text { czytelność granic } \\
\text { jednostki }\end{array}$ & Przejrzysty układ zabudowy & 1 & + \\
\hline & $\begin{array}{l}\text { Wnętrza urbanistycz- } \\
\text { ne o zróżnicowanej } \\
\text { skali }\end{array}$ & $\begin{array}{l}\text { Różnorodność wnętrz w obrębie } \\
\text { osiedla }\end{array}$ & 1 & + \\
\hline & $\begin{array}{l}\text { Stopniowanie } \\
\text { poziomu prywatności } \\
\text { wnętrz }\end{array}$ & $\begin{array}{l}\text { Wyczuwalna hierarchizacja } \\
\text { przestrzeni pod względem } \\
\text { prywatności }\end{array}$ & 1 & + \\
\hline$\frac{\frac{c}{U}}{\frac{N}{N}}$ & $\begin{array}{l}\text { Zieleń - aspekt } \\
\text { estetyczny }\end{array}$ & Dużo zieleni w obrębie jednostki & 1 & + \\
\hline
\end{tabular}




\begin{tabular}{|c|l|l|c|c|}
\hline & $\begin{array}{l}\text { Brak przewidzianych } \\
\text { parkingów }\end{array}$ & $\begin{array}{l}\text { Brak zaprojektowanych miejsc dla } \\
\text { samochodów }\end{array}$ & 3 & - \\
\cline { 2 - 5 } & $\begin{array}{l}\text { Separacja ruchu } \\
\text { pieszego i kołowego }\end{array}$ & Podział ciągów na piesze i kołowe & 3 & - \\
\cline { 2 - 5 } & $\begin{array}{l}\text { Przejścia bramne } \\
\text { w budynkach }\end{array}$ & $\begin{array}{l}\text { Zapewnienie komunikacji między } \\
\text { zewnętrzem a wnętrzem jednostki }\end{array}$ & 3 & + \\
\cline { 2 - 4 }$\frac{\tilde{\sigma}}{\bar{\sigma}}$ & $\begin{array}{l}\text { Minimalizacja ruchu } \\
\text { kołowego wewnątrz } \\
\text { osiedla }\end{array}$ & $\begin{array}{l}\text { Przeznaczenie wnętrza jednostki dla } \\
\text { mieszkańców }\end{array}$ & 3 & + \\
\cline { 2 - 5 } & $\begin{array}{l}\text { Brak konieczności } \\
\text { przekraczania dróg } \\
\text { tranzytowych } \\
\text { w obrębie osiedla }\end{array}$ & $\begin{array}{l}\text { Drogi tranzytowe oddzielające } \\
\text { poszczególne sektory }\end{array}$ & 3 & + \\
\hline
\end{tabular}

Źródło: opracowanie własne

\subsection{WNIOSKI. STREFY PROBLEMATYCZNE}

Subiektywna ocena obecnego stanu osiedla pozwoliła wysunąć wniosek, że osiedle Szkolne w znakomitej większości posiada cechy obszaru dostępnego pieszo. Większość kryteriów, mających bezpośredni lub pośredni wpływ na stopień dostępności pieszej, pozostaje aktualnymi bądź ulepszonymi. Około 79\% sklasyfikowanych kryteriów oceniono pozytywnie. Poprawie uległa zwłaszcza różnorodność usług - wzrosła liczba lokali gastronomicznych i handlowych. Obserwacja, podparta wiedzą na temat oryginalnych założeń Nowej Huty (Ptaszycki, 1953; Juchnowicz, 2008), umożliwiła także wskazanie obszarów newralgicznych, w których pozytywne rozwiązania uległy rozmyciu, a w konsekwencji znacząco obniżyły jakość przestrzeni pieszej.

Wytyczenie stref problematycznych osiedla Szkolnego wynika z kryteriów szczegółowych ocenionych negatywnie podczas analizy. Są to przede wszystkim kwestie związane z organizacją miejsc parkingowych i stanem przestrzeni wspólnych. Potencjalnym działaniem, bezpośrednio ułatwiającym przemieszczanie się piechotą, jest głównie wydzielenie miejsc postojowych i zapobiegnięcie chaotycznemu parkowaniu. Świadome wytyczenie przestrzeni dla pojazdów może ochronić przestrzeń zieloną przed zniszczeniem - częstym zjawiskiem są samochody stojące na trawnikach. Ponadto praktycznym rozwiązaniem może być zwiększenie potencjału transportu rowerowego - rozwój infrastruktury ścieżek i utworzenie nowych stacji rowerów miejskich. Charakterystyczną cechą w strukturze urbanistycznej Nowej Huty, której pozostałości wciąż można dostrzec, był klarowny podział arterii pieszych poprzez różnicowanie poziomów chodników, rozdzielanie ich murkami i stopniami (Obrał, 2013). Remont i wprowadzenie tego rozwiązania na nowo może podkreślić przejrzystość podziału ruchu kołowego i pieszego. Zmniejszenie liczby samochodów parkujących we wnętrzu osiedla i świadoma organizacja miejsc postojowych mogą wpłynąć na przywrócenie zielonych, pierwotnie bardzo atrakcyjnych wnętrz urbanistycznych. 

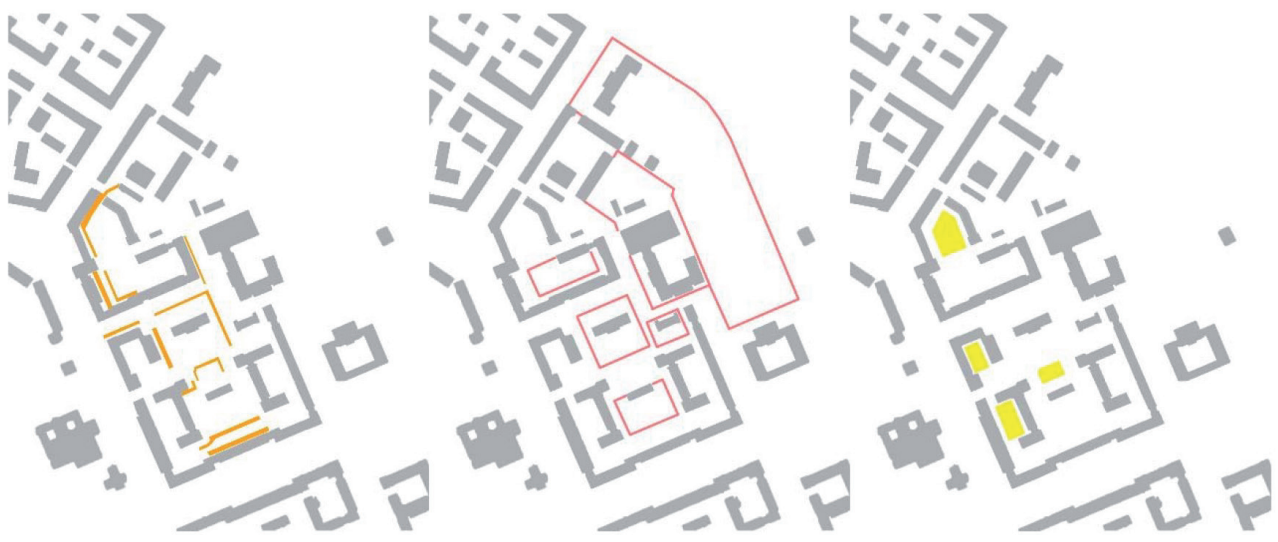

II. 13-15. Schematy reprezentujące lokalizację stref problematycznych: a) parkowanie na chodnikach, b) ogrodzenia, c) przestrzenie wspólne wymagające remontu i rewitalizacji. Oprac. własne

W artykule wskazano cztery dziedzińce wewnątrz jednostki, których rewitalizacja także może przyczynić się do zwiększenia różnorodności przestrzeni publicznych, obecnie skierowanych głównie do rodzin z małymi dziećmi. Remont oryginalnej fontanny, zagospodarowanie niewielkich placów, wprowadzenie małej architektury, obiektów aktywizujących i integrujących mieszkańców - są to działania konieczne do przywrócenia w pełni świetności osiedla. Przeprowadzone badanie oraz przedstawione wnioski mogą posłużyć za wskazanie władzom osiedla i mieszkańcom potencjalnego kierunku zmian.

\section{PODSUMOWANIE}

Dostępność piesza jest kluczową cechą związaną z dobrze funkcjonującym miastem. Dzięki niej mieszkańcy mogą dojść do niezbędnych usług. Należy zwrócić jednak uwagę, jak wiele czynników nakłada się na ten aspekt. Opisane w artykule kryteria pokazują złożoność problematyki pieszej dostępności oraz czynniki niezbędne do jej realizacji. Pierwotne założenia planu Nowej Huty już na etapie projektu uwzględniały piesze potrzeby mieszkańców poszczególnych osiedli. Badania terenowe zweryfikowały ich realizację i aktualny stan. Zaproponowane działania mają szansę poprawić stopień dostępności pieszej osiedla Szkolnego. Zmiany, wydawać by się mogło, na tak małym obszarze, jakim jest jedno osiedle, są niezwykle ważne. Dotyczą przecież miejsca zamieszkania, czyli najbliższego otoczenia człowieka. W kontekście omawianej w literaturze „odporności” miast (Kete, 2015; Czachor, 2019; Mehmood, 2016; Mendizabal et al., 2018; Sharifi, Yamagata, 2014) dostępność piesza zdaje się być elementem kluczowym. Dzięki poprawieniu dostępności jednego osiedla, przyczyniamy się do wzrostu odporności jednostki, a w rezultacie całego miasta. 


\section{BIBLIOGRAFIA}

Czachor, R. (2019). Koncepcja urban resilience: założenia, treść, możliwość implementacji. Społeczności Lokalne. Studia Interdyscyplinarne, (3), 127-148.

Czornik, M. (2013). Miasto i jego produkty. Studia Ekonomiczne / Uniwersytet Ekonomiczny w Katowicach, 147, 36-52.

Dovey, K., Pafka, E. (2019). What is walkability? The urban DMA. Urban Studies, 57(1), 93-108. Forsyth, A. (2015). What is a walkable place? The walkability debate in urban design. URBAN DESIGN International, 20, 274-292.

Gehl, J. (2014). Miasta dla ludzi, tłum. Szymon Nogalski. Kraków: Wydawnictwo RAM. Juchnowicz, S. (2008). Nowa Huta, przeszłość i wizja - z doświadczeń warsztatu projektowego. W: J. Salwiński, L.J. Sibila (red.), Nowa Huta przeszłość i wizja. Studium muzeum rozproszonego. Kraków: Muzeum Historyczne Miasta Krakowa.

Kenworthy, J.R., Newman, P. (2006). Urban Design to Reduce Automobile Dependence. Opolis: An International Journal of Suburban and Metropolitan Studies, 2(1), 36-36.

Kete, N. (red.). (2014). City Resilience Framework. London: The Rockefeller Foundation, Arup International Development.

Klaś, J. (red.). (2018). Nowa Huta. Architektoniczny portret miasta drugiej połowy XX wieku. Kraków: Ośrodek Kultury im. C.K. Norwida.

Klaś, J. (2016). Nowa Huta jako przykład przestrzeni zaprojektowanej z myślą o mieszkańcach. Kultura Współczesna, 4(92).

Konarski, L. (2019). Ballada o Nowej Hucie. Pobrane z: https://www.tygodnikprzeglad.pl/ ballada-o-nowej-hucie/ (dostęp: 20.03.2021).

Luchter, B. (2011). Przemiany użytkowania ziemi w Nowej Hucie w okresie 60 lat jej istnienia. Świat Nieruchomości, 75, 4-11.

Marcinek, R., Myczkowski, Z. (2017). Czas na Nową Hutę - o planie ochrony Parku Kulturowego Nowa Huta. Ochrona Zabytków, 1, 129-161.

Mądrala, N., Piła, K. (2019). Urbanistyka Nowej Huty - wady i zalety. Pobrane z: http://urbnews.pl/urbanistyka-nowej-huty-wady-zalety/ (dostęp: 20.03.2021).

Mehmood, A. (2016). Of resilience places: planning for urban resilience. European Planning Studies, 24(2),407-419.

Mendizabal, M., Heidrich, O., Feliu, E., García-Blanco, G., Mendizabal, A. (2018). Stimulating urban transition and transformation to achieve sustainable and resilient cities. Renewable and Sustainable Energy Reviews, 94, 410-418.

Obrał, A. (2013). Projekt rewitalizacji przestrzeni publicznych wzdłuż Alei Solidarności w Nowej Hucie. Przestrzeń i forma, 19, 163-176.

Paduchowski, W. (2012). U początków Nowej Huty. Spór o genezę usytuowania kombinatu i miasta. W: Ł. Kamiński, G. Wołek (red.), Zimowa Szkoła Historii Najnowszej 2012. T. 1 (s. 85-92). Warszawa. 
Państwowa Komisja Wyborcza. (2018). Wybory samorzqdowe 2018. Pobrane z: https:// wybory2018.pkw.gov.pl/pl/geografia/126101/pollstation/372\#protocol_95411 (dostęp: 23.03.2021).

Poklewski-Koziełł, D. (2019). W kierunku miasta bez samochodów. Przestrzenie dla pieszych w wybranych zespołach urbanistycznych w Europie (Rozprawa doktorska). Kraków.

Ptaszycki, T. (1953). Nowa Huta. Architektura, 3, 71.

Public Square. A CNU Journal. (2021). Defining the 15-minute city. Pobrane z: https://www. cnu.org/publicsquare/2021/02/08/defining-15-minute-city (dostęp: 23.03.2021).

Radłowska, R. (2008). Inżynier, który wymyślił Nowq Hutę. Pobrane z: https://krakow.wyborcza. pl/krakow/1,42699,4888231.html (dostęp: 20.03.2021).

Sharifi, A., Yamagata, Y. (2014). Resilient urban planning: Major principles and criteria. Energy Procedia, 61, 1491-1495.

Skrzypek, M. (2016). Atlas sytuacji pieszych. Lublin: Fundacja tu obok.

Smaga, M. (2012). Lata 60. w Nowej Hucie - urbanistyka, architektura i wnętrza. W: K. Jurewicz (red.), Nowa Przestrzeń. Modernizm w Nowej Hucie. Kraków: Muzeum Historyczne Miasta Krakowa.

Sumorok, A. (2015). Idea miasta socjalistycznego. Przypadek Nowej Huty. Czasopismo Techniczne, 12-A, 303-340.

Szczypiór, H. (2020). Nowa Huta - historia miasta, które stało się dzielnicq Krakowa. Pobrane z: https://podroze.onet.pl/ciekawe/nowa-huta-historia-miasta-ktore-stalo-sie-dzielnica-krakowa/jm6z9fp (dostęp: 20.03.2021).

Walczak, A. (2018). Procesy zachodzq̨ce w krajobrazie Nowej Huty-rozwój versus destrukcja przestrzeni (Rozprawa doktorska). Kraków. 